Short communication

\title{
A new generation of Large Animal ventilators
}

\author{
Yves P. Moens' ${ }^{1}$, W. Stetson Hallowell' ${ }^{2}$, Johannes P. Schramel ${ }^{1}$ \\ ${ }^{1}$ Anaesthesiology and perioperative Intensive-Care Medicine, University of Veterinary Medicine Vienna, Vienna, Austria \\ 2 Hallowell EMC, Pittsfield, MA, USA
}

\begin{abstract}
Summary: Most commercial large animal ventilators rely on the bag-in-the- box principle system where compressed gas is the driving power to drive a volume of gas into the lungs via a large animal circle system. A new generation of ventilators use special electrical motors and arrangements to force a volume of gas into the lungs. Two examples are the Tafonius (Vetronics Services) which is on the market and the Horsevent which has been developed as an University funded project (University of Veterinary Medicine Vienna). Tafonius uses a rigid piston in a cylinder with a rolling diaphragm. The piston is driven by an electronically controlled linear actuator. Airway pressure is measured at the Y-piece of the breathing circuit. This set-up allows precise control of pressures during spontaneous ventilation with or without continuous positive airway pressure and intermittent positive pressure ventilation (pressure and volume controlled mode) with maximum peak inspiratory and end- expiratory pressures of $80 \mathrm{~cm} \mathrm{H}_{2} \mathrm{O}$ and $50 \mathrm{~cm} \mathrm{H}_{2} \mathrm{O}$ respectively. In the Horsevent a linear motor operated in a forcecontrolled mode drives a standing concertina type of bellow. The ventilator which has no pressure sensor can be used in a spontaneous breathing mode with or without continuous positive airway pressure as well as in pressure controlled intermittent positive pressure ventilation with maximum peak inspiratory and end- expiratory pressures of $60 \mathrm{~cm} \mathrm{H}_{2} \mathrm{O}$ and $30 \mathrm{~cm} \mathrm{H}_{2} \mathrm{O}$ respectively. Manual operation of the concertina via the linear motor is possible at any time. Both ventilator designs carry substantial advantages over their bag-in-the box counterparts. Instead of costly compressed gas they need only electrical power and they function in an almost silent way. Both ventilators can also be used during spontaneous ventilation thereby avoiding disconnection or switching to an additional breathing bag. Both have direct microprocessor control of gas movement with ability to generate almost any desired pattern during inspiration and expiration and a large range of end-expiratory pressures. These features allow the implementation of modern ventilatory strategies including lung expansion maneuvers.
\end{abstract}

Keywords: Large animal ventilator, Tafonius, Horsevent, bag-in-the-box, anethesia

Citation: Moens Y. P., Hallowell W. S., Schramel J. P. (2016) A new generation of Large Animal ventilators. Pferdeheilkunde 32, 443-448

Correnspondence: Prof. Yves P. Moens, Anaesthesiology and perioperative Intensive-Care Medicine, University of Veterinary Medicine Vienna, Veterinaerplatz 1,A-1210Vienna, Austria; E-mail: yves.moens@vetmeduni.ac.at

\section{Introduction}

Until today, almost all commercial large animal ventilators rely on the bag-in-the-box principle system (Figure 1) to provide an isolating interface between the breathing system gases and the driving force that powers intermittent positive pressure ventilation (IPPV). Compressed gas is the driving power to force a bag or bellow to empty and drive a volume of gas into the lungs via a large animal circle system. The way the driving gas acts on the bag can be changed by the anesthetist via different controls but the available ventilation modes differ according to the manufacturer (Fowler et al. 1963, Smith 1964). These comprise e.g. pressure and volume limited ventilation, controlled or assisted operation modes and combinations. Positive end- expiratory pressure (PEEP) is mostly not available with these machines or only at a limited value of $10 \mathrm{~cm} \mathrm{H}_{2} \mathrm{O}$. These ventilators need a source of considerable compressed gas and are relatively noisy during operation.

Nowadays a new generation of large animal ventilators offers an interesting alternative to the aforementioned classical designs. These new ventilators use special electrical motors and arrangements to force a volume of gas into the lungs. One ventilator (Tafonius, Vetronic Services, Figure 2) is on the market and today used in more than forty centers all over the world. It is available as a stand-alone device or integrated in a dedicated anesthetic machine. Another design has been developed as an University funded project and is not yet commercially available (Horsevent, University of Veterinary Medi- cine Vienna, Figure 3). Thanks to microprocessor capabilities, direct electrical control over the movement of the breathing gases, via a piston (Tafonius) or a ridged bellows (Horsevent), can be achieved in any desirable pattern and so both machines offer a plurality of ventilation modes including a wide range of PEEP. In the absence of an integrated flowmeter they display a full set of respiratory parameters some measured and some calculated from the sole performance of the motor and concertina bag or piston assembly. Both ventilators can also be used during spontaneous ventilation thereby avoiding disconnection or switching to an additional breathing bag.

\section{Tafonius}

Tafonius uses a rigid piston in a cylinder with a rolling diaphragm to seal the breathing gas inside the breathing system (Figure 4). The piston is driven by an electronically controlled linear actuator providing a resolution of $25 \mathrm{~mL}$ and airway pressure is measured directly at the Y-piece of the breathing circuit. This set-up allows precise control of pressures during spontaneous ventilation and IPPV (pressure and volume controlled mode) including PEEP and continuous positive airway pressure (CPAP).

During spontaneous breathing, the piston is moved to keep the pressure at the $Y$ piece zero (airway servo system). In this way, the machine works to eliminate the work of breathing normally imposed on the patient by resistance in the tubing, 
soda-lime and valves. To the patient it feels like breathing from room air, albeit through an endotracheal tube. This works regardless of the design of the circle system to which the ventilator is connected and is instead particular importance in CPAP.

Whenever the piston volume exceeds the upper volume limit, gas is automatically dumped from the system. If the piston volume falls below the lower volume limit then gas is added to the system. The virtual bag concept minimizes the system volume and allows the circle to act as a closed system unless or until excess gas needs to be removed. With such a system the supplied oxygen gas flow can approach metabolic demand and avoids waist of volatile anesthetics and pollution.

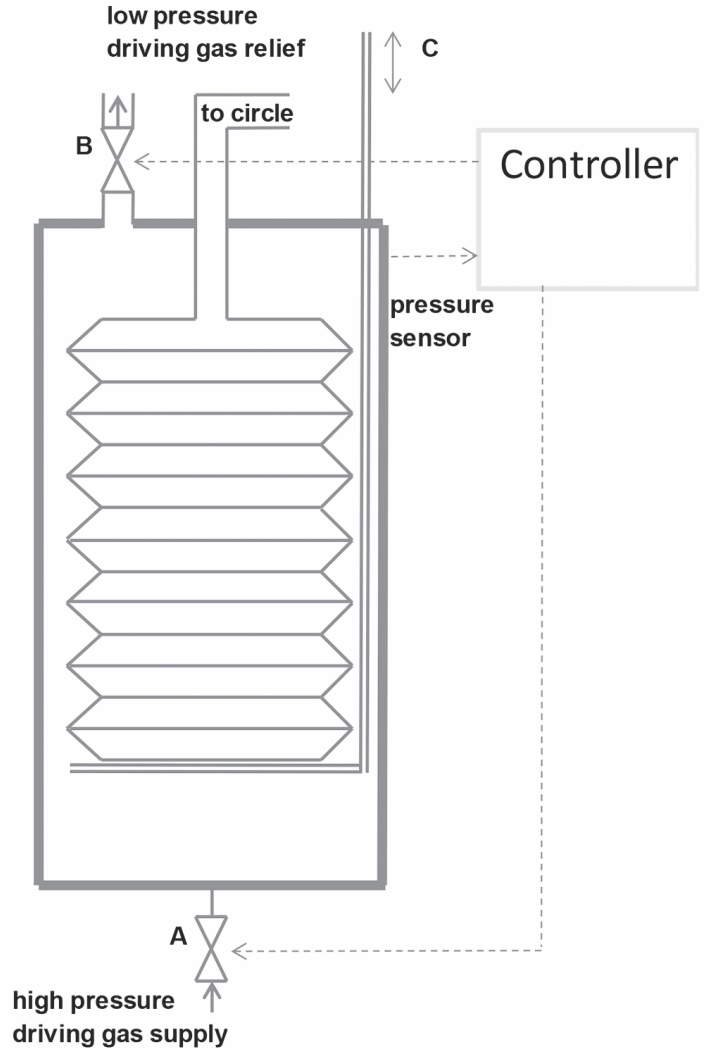

Fig. 1 Functional diagram of a Bag-in-the-box ventilator. The bag which contains respiratory gas is connected to the patient via an anesthetic circle system and is suspended in an airtight box. A controller unit measures the pressure inside the box and controls the driving gas valve $A$ and the box relief valve $B$ alternately according to the desired ventilation pattern. The pressure in the bag and in the box is the same. It is a pressure controlled ventilation with volume limiter. The latter function is provided with an adjustable rod $C$ that limits the extension of the bag and in turn the inspiratory volume. Inspiratory and expiratory flow can be adjusted via the driving gas and the box relief flow respectively.

Funktionsbeschreibung von einem Ventilator basierend auf dem Bagin-the-Box system. Ein Balg ist an das Kreissystem angeschlossen und hängt in einem luftdichten Behälter. Ein Controller misst den Druck in dem Behälter und öffnet zeitgestevert je nach dem gewünschten Beatmungsmuster ein Druckventil A das Druckluft (Treibgas) in den Behälter einlässt und den Balg komprimiert. Mit einem ebenfalls gesteverten Auslassventil B wird der Druck wieder abgelassen. Der Druck im Balg und im Behälter ist gleich. Damit kann eine druckkontrollierte Beatmung erzielt werden. Mit einem verstellbaren Anschlag C kann zusätzlich das Volumen des Balges und damit das Tidalvolumen begrenzt werden. Mit dem Gasfluss durch die Ventile $A$ und $B$ können Inspirations und Exspirationszeiten begrenzt werden.

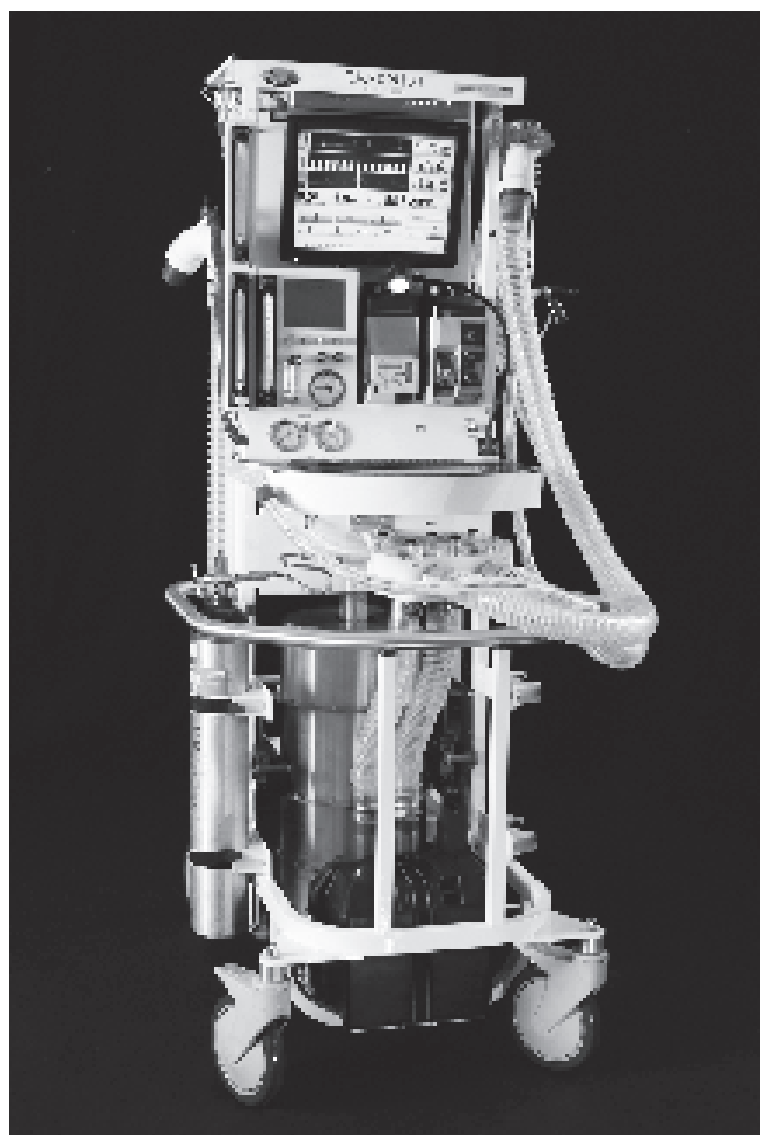

Fig. 2 The Tafonius entilator and Anesthesia system Das Tafonius Beatmungs- uns Anästhesiegerät

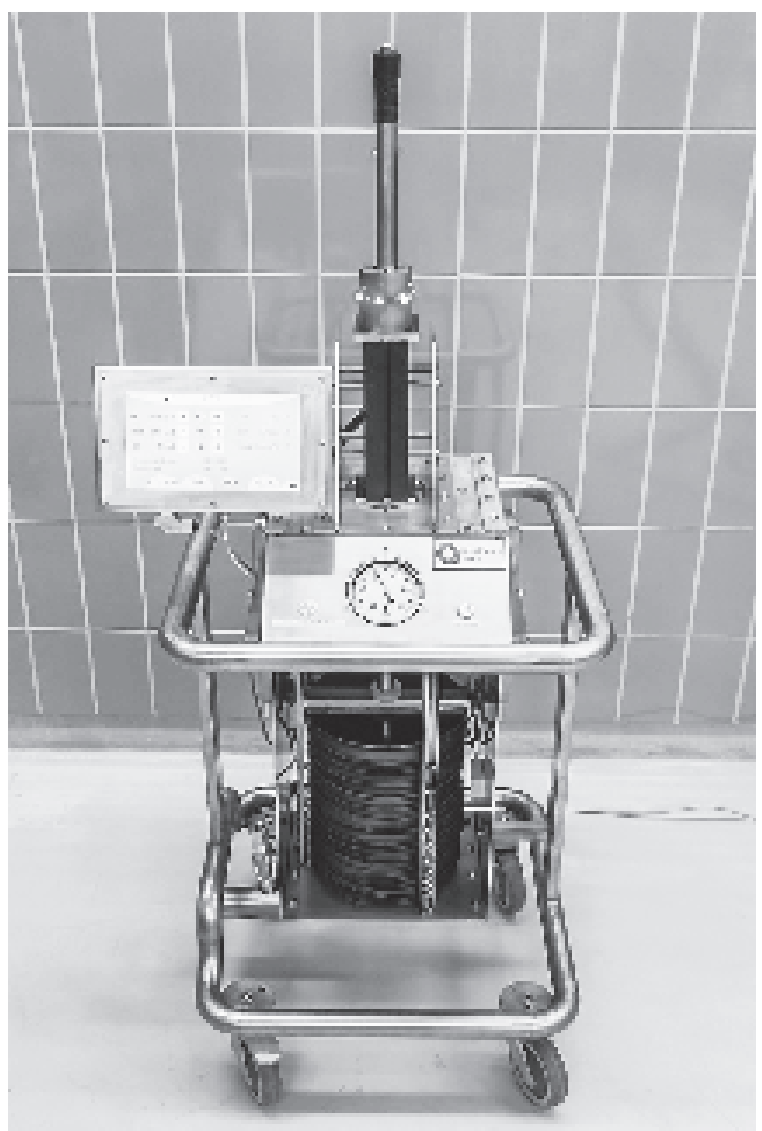

Fig. 3 The Horsevent Ventilator Das Horsevent Beatmungsgerät 
Through the direct control of the breathing gas peak inspiratory and positive end expiratory pressures can accurately and quikkly be applied. Tafonius allows a maximum PIP and PEEP of $80 \mathrm{~cm} \mathrm{H}_{2} \mathrm{O}$ and $50 \mathrm{~cm} \mathrm{H}_{2} \mathrm{O}$ respectively. Displayed values for airway pressures and volumes are measured and calculated respectively and continuously updated. These features allow the implementation of modern ventilatory strategies including lung expansion maneuvers (Moens and Böhm 2011).

\section{Horsevent}

The Horsevent is connected to an existing large animal circle system instead of the standard breathing bag. A linear motor drives a standing concertina type of bellow which is suspended in a robust metal frame (Figure 5). This linear motor consists of two parts: a stator and a slider, both not connected by brushes or cables. The slider contains strong neodymium magnets assembled in a rod, which actuates the bellows. A linear motion is generated directly by electromagnetic forces provided by a current through the stator coils. A dedicated bearing allows low friction linear movement of the rod. A motor controller monitors the position of the rod by switching the stator currents in an appropriate manner. The linear motor of the Horsevent is operated in a force-controlled, not a position- controlled mode. During setup, a calibration routine learns and stores the required motor current needed to

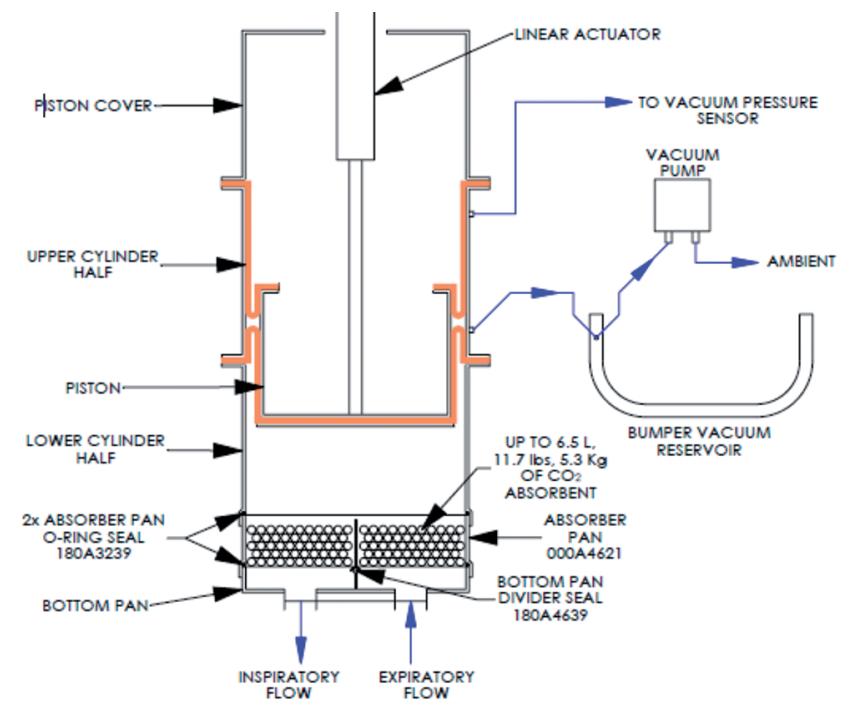

Fig. 4 Partial schematic diagram of the Tafonius. A linear actuator moves a piston in an cylinder according to the required breathing pattern. Dual rolling diaphragms (RD) seal the breathing gases in the breathing system and provide smooth frictionless movement of the piston. The absorber is integrated at the bottom of the cylinder. The lower RD seals the system the upper RD creates a space between the RDs upon which a vacuum can be drawn thereby drawing and holding the RDs tight against the cylinder and piston walls to insure smooth operation. At the bottom of the cylinder the absorber is attached to..

Schema von Tafonius Beatmungsgerät. Ein Linear Aktuator bewegt den Stempel entsprechend des gewünschten Beatmungsmusters. Zwei Rollmembranen (RD) trennen das Atemgas von der Umgebungsluft und erlauben eine reibungsarme Bewegung des Stempels im Beatmungszylinder. Im Raum dazwischen herrscht ein Vakuum damit die Membranen an der Wand anliegen. An Boden des Zylinders ist der Absorber integriert. levitate all moving parts at every stretching of the bellow. Thus during spontaneous ventilation (virtual bag mode) the weight of the standing concertina is compensated by a position dependent motor current. To provide a selected pressure an appropriate force is exerted on the bellow which is proportional to the motor current (I). The resulting pressure is then $P \sim I / A$ with $(A)$ the surface area of the bellows on which the force acts. Thus, generated pressures are independent of the volume in the concertina.

The ventilator can be used in a spontaneous breathing mode (virtual bag mode) with or without CPAP as well as in pressure controlled IPPV modus with PIP and PEEP up to $60 \mathrm{~cm} \mathrm{H}_{2} \mathrm{O}$ and $30 \mathrm{~cm} \mathrm{H}_{2} \mathrm{O}$ respectively. Additionally the controller provides advanced ventilation features such as semi-automatic lung expansion maneuvers, biologically variable ventilation and assisted spontaneous ventilation with CPAP for further clinical investigations. The absence of an electronic pressure or flow sensor leads to a robust design. Displayed values for airway pressures and volumes are calculated and continuously updated.

One of the particular features is that at any time manual operation of the concertina via the linear motor is possible. Simi-

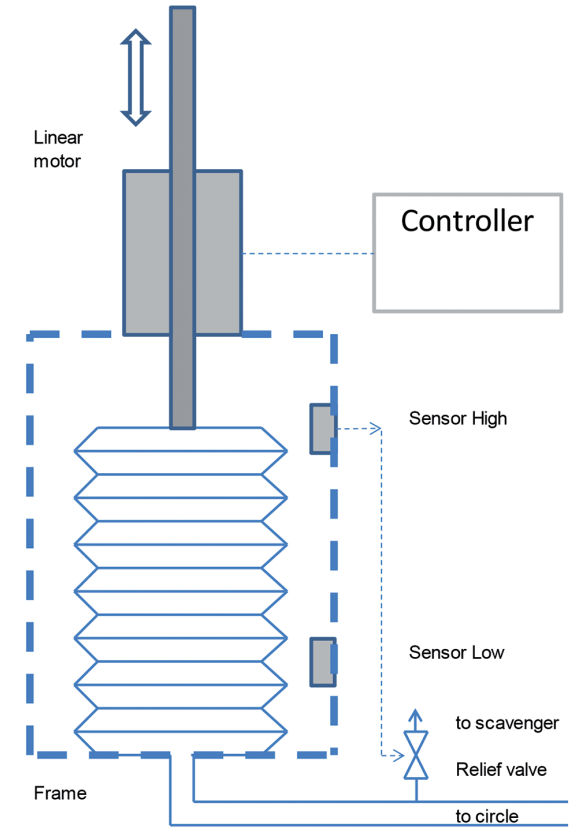

Fig. 5 Schematic diagram of the Horsevent Ventilator. A linear motor is operated by a controller to compensate the weight of the standing bellow in any vertical position and to provide the appropriate additional forces for pressure controlled ventilation with or without PEEP or CPAP. A sensor High indicates bellow full and opens a relief valve to release excessive air from the breathing system. A sensor Low indicates bellow empty with an acoustic signal. This prompts the anaesthetist to increase fresh gas flow or to look for leaks in the system.

Schema von Horsevent Beatmungsgerät. Ein Linearmotor wird von einem Controller derart gestevert, dass das Gewicht des stehenden Balges in jeder vertikalen Stellung in Schwebe gehalten wird. Durch eine davon abweichende Kraft des Linearmotors können die gewünschten Beatmungsdrucke PIP und PEEP oder CPAP erzeugt werden. Der Sensor High detektiert wenn der Balg voll ist und öffnet ein Ablassventil. Mit einem Sensor Low der anzeigt wenn der Balg leer ist wird ein akustisches Signal ausgegeben um den Anästhesiten zu veranlassen mehr Frischgas in das Kreissystem zu geben oder nach einem Leck im System zu suchen. 
lar to the effect of manual compression of a breathing bag the rod can be pushed down by hand to give additional breaths if needed. After use the ventilator can be set in dry mode. The device aspirates and exhausts intermittently fresh dry air to remove moisture and traces of volatile anesthetics from the system.

\section{Conclusion}

Both ventilator designs carry substantial advantages over their bag-in-the- box counterparts. First, they have eliminated the pneumatic driving gas layer between the electronics and the displacement of gas through the breathing system into the patient. Instead of costly compressed gas they need only electrical power and they function in an almost silent way. The latter particularly contributes to a favorable environment in the operation room. In case of electrical mains failure both designs have backup options. The Horsevent allows for manual ventilation without power, whereas Tafonius will continue seamless operation on batteries for four hours at which point a manual breathing bag must be used. Second both ventilators have direct microprocessor control of gas movement with ability to generate almost any desired pattern during inspiration and expiration. This includes the possibility of spontaneous respiration, the use of CPAP and a large range of PEEP during IPPV. These features allow not only for the application of recently introduced ventilatory strategies but also offer the flexibility to cope with possible future new concepts for optimal ventilation in the horse.

\section{Acknowledgements}

Stetson Hallowell is thanked for reviewing the text of this manuscript and the information about Tafonius in particular

\section{Conflict of Interest}

The Tafonius was developed by Stetson Hallowell and Keith Simpson. Further information about Tafonius can be obtained atenquiries@vetronic.co.uk.

The Horsevent was developed by JX Brunner and SH Böhm (CSEM and Swisstom, Switzerland), J. P. Schramel and Y. P. Moens (University of Veterinary Medicine Vienna).

Software development and user interface design was done by D. Krieger and S. Tabacariu respectively (University of Applied Sciences, FH Campus Vienna). Further information about the Horsevent can be obtained from J. P. Schramel (johannes. schramel@vetmeduni.ac.at).

\section{References}

Fowler M., Parker E., Mc Laughlin R., Tyler W. (1963) An inhalation anesthetic apparatus for large animals. J. Am. Vet. Med. Assoc. 143, 272-276

Moens Y., Böhm S. (2011) Ventilating horses:moving away from old paradigms. Vet. Anaesth. Analg., 38,165-168

Smith M. (1964) A respirator for large animals. Nord. Vet. Med. 23, 537-547
Erweiterte Zusammenfassung

\section{Eine neue Generation Großtierbeatmungsgeräte}

Die meisten herkömmlichen Großtier-Beatmungsgeräte basieren auf dem Bag-in-the-Box-Prinzip und werden mit Druckluft betrieben. Ein Beutel oder ein Balg ist in einem luftdichten Behälter befestigt und trennt das Atemgas vom Treibgas (Abbildung 1). Durch Erhöhung des Druckes im Behälter wird der Balg komprimiert und drückt über ein Kreissystem das Atemgas in die Lunge. Grundsätzlich handelt es sich dabei um eine druckkontrollierte Beatmung. Jedoch kann auch durch Begrenzung des Volumens des Balges eine volumenkontrollierte Beatmung realisiert werden. Die neve Generation von Beatmungsgeräten verwenden spezielle Elektromotoren als Antrieb die einen Stempel in einem Zylinder oder auch einen Balg bewegen um das Atemgas unter Druck zu setzen und über das Kreissystem die Lunge zu belüften. Beispiele dafür sind Tafonius, Vetronic Services (Abbildung 2), der kommerziell entweder als Kombination mit einem Narkosegerät oder als Beatmungsgerät alleine erhältlich ist und Horsevent (Abbildung 3) der im Rahmen eines geförderten Projektes an der Veterinärmedizinischen Universität Wien entwickelt wurde. Die Kurzmitteilung gibt einen Überblick über die Funktionsweise und Möglichkeiten beider Geräte.

\section{Tafonius}

Tafonius (Abbildung 4) verwendet einen starren Kolben in einem Zylinder. Rollmembranen dichten den Kolben ab und trennen das Atemgas von der Umgebungsluft. Zwischen den Rollmembranen herrscht ein Vakuum und ermöglicht damit eine reibungsarme Bewegung. Der Kolben wird von einem elektronisch gesteverten Linearaktuator angetrieben und kann den Kolben mit einer Auflösung von $25 \mathrm{ml}$ bewegen. Der Atemwegsdruck wird direkt am Y-Stück des Beatmungskreislaufes gemessen. Dieser Aufbau ermöglicht eine präzise Kontrolle der Drücke bei IPPV und ermöglicht einen Druck und Volumen gesteverten Betrieb einschließlich PEEP und kontinuierlichem positiver Atemwegsdruck (CPAP). Bei Spontanatmung wird der Kolben entsprechend den Atembewegungen so gestevert dass der Druck am Y-Stück null bleibt (Servosystem). Deshalb spielen Strömungswiderstände im Kreissystem keine Rolle. Der Patient kann daher ohne Erhöhung der Atemarbeit wie natürlich spontan atmen obwohl er an ein Kreissystem mit Absorber und Ventilen angeschlossen ist. Das ist von besonderer Bedeutung bei der Anwendung von CPAP. Wenn der Kolben die obere Volumengrenze überschreitet beispielsweise durch einen Überschuss an Frischgas, wird Gas automatisch aus dem System abgelassen und die Kolben Lage bewegt sich wieder in eine mittlere Position. Erreicht dagegen der Kolben die untere Volumengrenze, dann wird automatisch die Frischgaszufuhr zum Kreissystem erhöht. Das System kann daher bei Anpassung der Frischgaszufuhr mi† $100 \%$ Saverstoff an den metabolischen Bedarf des Patienten als geschlossen betrachtet werden. Das Anfallende $\mathrm{CO}_{2}$ wird im Absorber gebunden sodass kein Gas nach außen abgegeben werden muss. Diese Betriebsart führt zu einem minimalen Verbrauch an Anästhetika und vermeidet eine Belastung der Umwelt durch Narkosegase. Tafonius erlaubt einen maximale PIP Wert von $80 \mathrm{~cm} \mathrm{H}_{2} \mathrm{O}$ und PEEP Werte bis zu $50 \mathrm{~cm} \mathrm{H}_{2} \mathrm{O}$. Die Werte für Atemwegsdruck und Volumen werden gemessen und entsprechend der Kolbenbewegung berechnet. Diese Konstruktionsdetails erlauben grundsätzlich die Umsetzung 
von allen modernen Beatmungsstrategien die auch nachträglich programmiert werden können.

\section{Horsevent}

Der Horsevent wird an ein bestehendes Großtierkreissystem an Stelle des normalen Atembeutels angeschlossen. Ein Linearmotor bewegt einen stehenden Balg der in einem Metallrahmen seitlich reibungsarm gelagert ist aufgehängt ist. Dieser Linearmotor besteht aus zwei Teilen: einem Stator und einem darin reibungsarm gelagerten beweglichen Stab. Der Stab enthält starke Neodym-Magnete mit alternierender Polarität und ist mit dem Balg starr verbunden (Abbildung 5). Eine lineare Bewegung wird durch entsprechende elektrische Ströme in den Stator Spulen ausgelöst. Dabei ist die entstehende Kraft proportional dem Strom in den Motorwicklungen. Ein Motor-Controller errechnet die notwendigen Ströme und überwacht die Position der Stange. Eine spezielle Lagerung führt den Stab reibungsarm nur mit einem kleinen Luftspalt im Stator. Der Linearmotor des Horsevent wird in einem kraftgesteverten und nicht in einem lagegeregelten Modus betrieben. Mit einer Kalibrationsroutine lernt und speichert der Motorcontroller den benötigten Motorstrom (Offset) um alle beweglichen Teile in jeder Lage schweben zu lassen. Je länger der Balg ausgezogen wird desto größer muss die Gegenkraft sein. Während Spontanatmung arbeitet der Motor im Virtual Bag Mode so das sich der Balg trotz seines Gewichtes kraftlos bewegen kann. Um einen gewünschten Druck zu erzielen ist eine entsprechende Kraft auf dem Balg notwendig. Dazu wird zu dem in der Kalibrationsroutine ermitteltem Strom (Offset) ein dem gewünschten Druck entsprechender Motorstrom dazu addiert. Die so erzeugten Drücke sind unabhängig von dem Volumen im Balg.

Das Beatmungsgerät kann Drücke bis $60 \mathrm{~cm} \mathrm{H}_{2} \mathrm{O}$ und PEEP /CPAP bis zu $30 \mathrm{~cm} \mathrm{H}_{2} \mathrm{O}$ erzeugen. Bei Spontanatmung arbeitet das Gerät im Virtual Bag Modus. Der Controller bietet weitere Möglichkeiten wie ein halbautomatisches Recruitment Manöver, biologisch variable Beatmung (variabler Druck und/ oder Atemfrequenz) und Druckunterstützung beim Ein- und Ausatmen im CPAP Modus. Die Vermeidung von Druck- oder Durchflusssensoren führt zu einem robusten Design mit trotzdem ausreichender Genauigkeit der einge- stellten Parameter. Die angezeigten Werte für einen mittleren Atemwegsdruck und Tidal- und Minutenvolumen werden berechnet und laufend aktualisiert.

Ein besonderes Merkmal ist die jederzeit mögliche manuelle Betätigung des Stabes des Linearmotors und damit des Balges sowie die direkte optische Kontrolle der Auf- und Abbewegung des Balges. Damit kann jederzeit händisch in die automatische Beatmung eingegriffen werden in dem ähnlich der manuellen Kompression des Atembeutels die Stange händisch nach unten gedrückt wird, um beispielsweise zusätzliche Atemzüge zu geben, falls gewünscht. Auch kann damit mit etwas Erfahrung ebenso wie beim Atembeutel die Compliance der Lunge erfühlt werden. Nach dem Gebrauch kann das Gerät in einen Trocknungsmodus gesetzł werden. Dazu saugt das Gerät intermittierend frische trockene Luft an und bläst diese wieder aus um Feuchtigkeit und Spuren von volatilen Anästhetika aus dem System zu entfernen.

Beide Ausführungsformen haben wesentliche Vorteile gegenüber dem Bag-in-Box Konzept. Ein Elektrischer Antrieb ersetz† die bei herkömmlichen Ventilatoren notwendige Druckluft zum Betrieb und erlaubt damit einen fast geräuschlosen Betrieb im Operationssaal. Letzteres trägt insbesondere zu einem ruhigen Umfeld im Operationssaal bei. Beide Geräte haben Lösungen für einen Ausfall der Stromversorgung. Während Tafonius über eine Backup Stromquelle für 4 Stunden Betrieb verfügt, kann beim Horsevent durch manuelle Betätigung des Linearmotors händisch weiter beatmet werden.

Durch die Steuerung der Ein- und Ausatmung und der Drücke oder Volumina mit einem Computer oder Microcontroller kann jedes gewünschte Beatmungsmuster erzeugt werden. Dies schließt die Möglichkeit der Spontanatmung, die Verwendung von PEEP, CPAP assistierte Beatmung ein. Diese Funktionen ermöglichen es neve Strategien der Beatmung zu evaluieren und einen Beitrag zur optimalen Saverstoffversorgung in der Allgemeinanästhesie beim Pferd zu leisten.

Stichwörter: Großtierbeatmungsgerät, Tafonius, Horsevent, bag-in-the-box, Anästhesie, Pferd 